WAYNE VROMAN

University of Maryland

\title{
Worker Upgrading and the Business Cycle
}

CyCliCAl swings in real economic activity are accompanied by largescale adjustments in the labor market. Arthur Okun has noted that the industries most sensitive to the business cycle pay high wages and employ primarily men aged 25 and older, the demographic group with the most stable attachment to the labor force. ${ }^{1}$ Thus when output and employment expand, workers are recruited from other industries and from the demographic groups that usually have lower earnings-that is, the young, blacks, and women. This recruitment process implies both income gains for people who move into the cyclically sensitive industries and a bonus in macroeconomic productivity because these industries are characterized by real output per manhour that is higher than the average.

Okun and Lester Thurow have argued further that continuous operation of the economy at full employment yields income gains to workers in lower-paying industries and occupations. ${ }^{2}$ According to their argument, the "high-pressure economy" is characterized by continuing recruitment and by opportunities for upward mobility which benefit disproportionately the young, blacks, and women. As the economy moves away from full

Note: Comments by members of the Brookings panel on an earlier version of the paper were very helpful.

1. Arthur M. Okun, "Upward Mobility in a High-Pressure Economy," $B P E A$, 1:1973, pp. 207-52.

2. See ibid; Lester C. Thurow, Poverty and Discrimination (Brookings Institution, 1969), chap. 4; and Lester C. Thurow and Robert E. B. Lucas, "The American Distribution of Income: A Structural Problem," prepared for the use of the Joint Economic Committee, 92:2 (Government Printing Office, 1972). 
employment, recruitment and upgrading opportunities diminish, and the associated income losses are borne most heavily by these same groups.

This report examines patterns of gains in real wages experienced by various labor force groups in different phases of the business cycle. ${ }^{3}$ The Social Security Administration's Continuous Work-History Sample (CWHS), a source of longitudinal data, is used to trace changes in real annual wages of workers. Because these data identify workers and employers by industry (but with scrambled identification numbers to preserve confidentiality), they can be used to examine some of the Okun-Thurow ideas about labor market behavior in the high-pressure economy. One can follow not only changes in employment by industry (as Okun has done), but also changes in annual wages for workers classified by demographic and industry characteristics and by job-mobility status (which Okun could not do). Specifically, the CWHS is used here to contrast the cyclical experiences of job stayers and job changers, and to measure the wage increases realized by workers who move into high-wage industries during periods of low unemployment.

\section{The CWHS Data}

A thorough test of the Okun-Thurow argument regarding the implications of a high-pressure economy requires longitudinal data that record both worker characteristics (age, race, sex, education, occupation) and job characteristics (wage level, fringe benefits, the risk of unemployment, and opportunities for advancement). With such data, one could observe how job mobility and worker upgrading vary cyclically. They would also permit a comparison of the merits of explanations for low-wage status that rely, respectively, on the concept of a dual (or segmented) labor market and on human capital.

The data from the Continuous Work-History Sample have many (but by no means all) of the elements necessary for investigating these questions. ${ }^{4}$ Since they are longitudinal data, they enable an investigator to follow wage and salary workers in employment subject to social security

3. This report summarizes a longer paper, Wayne Vroman, "Cyclical Earnings Changes of Low Wage Workers," Research in Labor Economics, vol. 2 (1978), forthcoming.

4. A more complete description of these data is found in ibid. 
contributions. They record the worker's age, race, and sex, as well as estimated annual wages in each job. Also included are the employer's account number (scrambled), standard industrial classification code, and geographic location. Thus job mobility and associated wage changes can be traced in these data. The sample is sufficiently large-more than a million workers in recent years-to yield statistically reliable results at detailed levels of disaggregation.

The deficiencies in CWHS data are also numerous and limit their usefulness in choosing among the major alternative hypotheses about lowwage status. Important characteristics of workers (education, occupation, marital status, and health status) are not available. Because social security coverage is not universal, these data exclude about 10 percent of wage and salary employment (mainly in the government sector). Annual wages for high-wage workers may involve error since they are extrapolated from reported wages up to the maximum subject to social security tax. Also the CWHS data on annual earnings have no breakdown for hours worked and hourly wage rates. Thus the term "low wages" as used here denotes low annual earnings due alike to low wage rates, low hours worked, or some combination of the two. Finally, zero earnings in CWHS data can reflect one of four states (1) nonparticipation in the labor force; (2) unemployment; (3) self-employment; or (4) noncovered employment.

Despite these deficiencies, the CWHS data do reveal the demographic composition of industry employment, the extent of job mobility, and the wage gains associated with job changes. They also permit comparison of average wage levels and rates of labor force turnover among industries. All of these are needed to assess arguments about the benefits of the highpressure economy. The plan of the paper is to examine the CWHS using tabular displays of data collected from different phases of the business cycle.

\section{Interindustry Differences in Wage Levels and Employee Turnover Rates}

Although good jobs are widely dispersed in the economy, some industries and occupations have much higher proportions than others. The precise definition of a good job can be debated, but some consensus 
appears in the literature. ${ }^{5}$ Cain has stressed financial returns, prestige, working conditions, and employment stability in defining the desirability of jobs in different occupations. Doeringer and Piore describe jobs in the primary sector of the dual labor market in terms of high wages, good working conditions, employment stability, good chances for advancement, and equity and due process in the administration of work rules. Class $\mathrm{A}$ firms in Okun's two-tier labor market pay a wage premium which promotes employment attachment and holds down turnover among workers. In all three of these perspectives, high pay (including fringe benefits) and low turnover signal good jobs.

Since wages and turnover can be measured in the CWHS, interindustry differences in average job quality were examined for the period 1964 to 1966. Wage and salary workers aged 25 to 64 in 1964 were classified into broad industries in each year according to their major job (the job of highest annual wages). Altogether, in addition to the armed forces there were twelve civilian industries (agriculture, mining and construction, durable manufacturing, nondurable manufacturing, transportation, wholesale trade, retail trade, finance-insurance-real estate, business and professional services, household services, other services, and government. ${ }^{\circ}$ Two employment turnover measures were calculated: (1) firm-specific retention rates, the fraction of 1964 workers employed by the same employer in 1966; and (2) employment dropout rates, the fraction of 1964 workers who had no covered wages in 1966.

The twelve civilian industries differed greatly in average wage levels and in the two turnover measures. ${ }^{7}$ Whatever their race or sex, workers in durable manufacturing, nondurable manufacturing, and transportation consistently experienced high wages and low turnover, relative to the all-industry avergae. Conversely, those in agriculture, retail trade, household services, and other services consistently had low wages and high

5. Three papers that discuss the distinguishing features of good jobs and bad jobs are Okun, "Upward Mobility"; Glen G. Cain, "The Challenge of Segmented Labor Market Theories to Orthodox Theory: A Survey," Journal of Economic Literature, vol. 14 (December 1976), pp. 1215-57; and Peter B. Doeringer and Michael J. Piore, Internal Labor Markets and Manpower Analysis (Heath, 1971).

6. This classification scheme closely follows the one used by Okun. Transportation, however, includes all of transportation, communications, and public utilities (SIC 40-49); and other services includes everything except business services, professional services, and household services.

7. See table 2 in Vroman, "Cyclical Earnings Changes." 
turnover. The other five civilian industries were generally found to be much closer to the all-industry averages. ${ }^{8}$

\section{The Cyclical Periods}

The time span for the analysis, 1964 to 1971 , comprises three distinct periods. Real output and employment expanded rapidly between 1964 and 1966, and the unemployment rate fell from 5.2 percent to 3.8 percent. In the years 1966 through 1969, the economy operated more or less continuously at full employment with aggregate unemployment rates of $3.8,3.8,3.6$, and 3.5 percent, respectively. These four years represent a high-pressure economy. A downturn in real activity occurred at the end of 1969 , and the overall unemployment rate rose to 4.9 percent in 1970 and to 5.9 percent in 1971; meanwhile, rates of wage and price inflation greatly exceeded those of previous postwar recessions.

Within this eight-year interval, three subperiods will be examined: 1964 to 1966 (a cyclical upturn), 1966 to 1968 (continuous full employment), and 1969 to 1971 (a cyclical downturn). Because the paper focuses on job changing and associated wage changes, the periods have been chosen to be of equal length. Annual wages (the wage rate times annual hours worked) and wage changes are expressed in real terms, based on the consumer expenditures deflator from the national income accounts.

\section{Cyclical Employment Changes by Industry}

The business cycle is known to have markedly different impacts on employment levels in various industries. Okun documented the magnitude of these differences, showing employment in durable manufacturing to be the most cyclically sensitive, while employment in agriculture and household services actually moves countercyclically. ${ }^{\circ}$ Retail trade was

8. Two exceptions to this statement should be noted. Wholesale trade and financeinsurance-real estate were both high-wage, low-turnover industries for white workers but not for blacks. Government was a high-wage, low-turnover industry for the three demographic groups other than white men.

9. Okun, "Upward Mobility," table 3, p. 224. 
found to have a cyclical employment elasticity roughly equal to the allindustry average.

Tabulations of the thirteen major industries in CWHS data yielded similar findings about employment sensitivity. Table 1 helps to illustrate some of these interindustry differences for the three periods. Two industries appear in the table, durable manufacturing and retail trade, along with the all-industry totals. These two were selected as representative, respectively, of good-job industries (high wages, low turnover) and badjob industries (low wages, high turnover).

Table 1 reveals the similarity of employment changes as recorded in the Department of Commerce data covering full- and part-time workers (which Okun used) and in the CWHS data on workers aged 16 to 64 . According to both, the largest gains in employment took place in the 1964-66 cyclical upturn and the smallest in the 1969-71 interval. The changes by industry also match rather closely in the two data sources, and both reveal the extreme cyclical sensitivity of employment in durable manufacturing.

For each of the thirteen major industries in this study, the CWHS employment data were also tabulated for various age-race-sex groups. Changes in the demographic composition of employment in durable manufacturing between 1964 and 1968 confirm Okun's observations that in buoyant labor markets high-wage employers draw new employees disproportionately from demographic groups other than prime-age white men. Total employment of persons aged 16 to 64 in durable manufacturing was 11.26 million in 1964 and 13.56 million in 1968. Of these totals, white men aged 25 to 64 accounted for 6.81 million and 7.56 million in the two years, respectively, thus constituting 60.5 percent of the 1964 employment level but only 32.6 percent of the employment change from 1964 to 1968.

Applying the CWHS data to trace individuals and groups of workers through time, table 1 also displays the employment changes in the three periods for cohorts of workers initially aged 16 to 64 . (The earnings gains of these cohorts will be examined below.) Changes for the cohorts for all industries are smaller than those for 16- to 64 -year-olds by 2 million or more workers in each interval, mainly reflecting employment of 16- and 17-year-olds in the three terminal years, 1966, 1968, and 1971 (subtract the entry in panel $C$ from that in panel B). The overall change in employment in retail trade contains a striking contrast: aggregate employment 
Table 1. Employment Changes, by Industry and Cyclical Period, 1964-71 Millions of workers

\begin{tabular}{lccr}
\hline \multicolumn{1}{c}{ Industry } & $1964-66$ & $1966-68$ & \multicolumn{1}{c}{$1969-71$} \\
\hline & \multicolumn{1}{c}{ A. Full- and part-time } & employees \\
Durable manufacturing & 1.50 & 0.34 & -1.34 \\
Retail trade & 0.87 & 0.70 & 0.53 \\
All industries & 6.23 & 4.02 & -0.32 \\
& \multicolumn{3}{c}{ B. All workers aged } \\
Durable manufacturing & 1.95 & 0.35 & -1.64 \\
Retail trade & 0.67 & 0.71 & 0.66 \\
All industries & 6.62 & 4.40 & 0.45
\end{tabular}

Durable manufacturing

C. Cohorts of workers initially aged 16-64

Retail trade

1.93

0.32

$-1.55$

All industries

$-0.79$

$-0.74$

4.42

1.76

$-1.59$

Durable manufacturing

D. Net entrances into employment by young workers

Retail trade

0.02

0.03

$-0.11$

1.30

1.50

1.40

All industries

2.21

2.64

2.04

E. Net entrances into employment by persons initially aged 16-64

Durable manufacturing

0.77

0.05

$-0.79$

0.91

0.50

0.06

4.42

1.76

$-1.59$

All industries

F. Net interindustry flows of employed workers initially aged 16-64

Durable manufacturing

Retail trade

1.16

$-1.54$

0.00
0.27

$-1.29$

0.00
$-0.76$

$-0.80$

0.00

Sources: Full- and part-time workers-U.S. Department of Commerce, The National Income and Product Accounts of the United States, 1929-74: Statistical Tables (Government Printing Office, 1977), table 6.7; all other data-unpublished tabulations from the Social Security Administration's One-Percent Continuous Work-History Sample. Figures are rounded.

a. Employment of 16- and 17-year-olds less the employment of 65- and 66-year-olds in the latter year of each cyclical period.

increased in each period but the cohort data record a net exit of workers from the industry in each. For durable manufacturing, on the other hand, the magnitudes of the employment changes for the aggregate and the cohorts are very similar.

Panels D, E, and F provide a three-way breakdown of the employment changes shown in panel $B$ that reveals differing patterns of recruiting and retaining workers. Over any period—say, from 1964 to 1966 - the change 
in industry employment of persons aged 16 to 64 can be broken into three components. First, there is the difference between the constant-age group (16- to 64-year-olds) and the cohort employment change-in this case, the difference between industry employment of those aged 16 to 64 and those aged 18 to 66 in 1966. Since the number of younger workers greatly exceeds the number aged 65 to 66 , panel $D$ reflects mainly the labor-force entry patterns of workers aged 16 and 17 . The second component (in panel $E$ ) is the net entrances into covered employment by persons initially aged 16 to 64 . For the 1964-66 period, this would be the number of 1966 workers who entered covered employment after 1964 less the number of 1964 workers who had dropped out of covered employment by 1966 . In durable manufacturing, this net inflow in 1964-66 was 0.77 million, the difference between 2.03 million entrants and 1.26 million dropouts. Hiring employed workers away from other industries is the third source of recruitment for an individual industry; the results appear in panel F. In the aggregate, this source of recruitment is zero, as one industry's gain is another's loss.

As indicated, panel $D$ reflects mainly the entrance into the labor force of workers aged 16 and 17. The gain of 2.64 million during 1966-68 exceeds the gain that would be predicted solely by population growth. In each period, about two-thirds of the new entrants initially worked in retail trade. Retail trade and services accounted for over 80 percent of all jobs taken by the young workers. At the opposite extreme, durable manufacturing recruits only a trivial number of workers in that age group. In fact, the negative entry for 1969-71 ( -0.11 million) means that more 65- and 66-year-olds than 16- and 17-year-olds were employed in durable manufacturing in 1971.

The effect of the business cycle on net recruitment into covered employment is very apparent in panel E. Among persons initially aged 16 to 64, 4.42 million more people entered covered employment than dropped out between 1964 and 1966, but between 1969 and 1971, 1.59 million more dropped out than entered. Undoubtedly, these large net movements are an important part of the way the labor market adjusts to changes in aggregate demand.

The net flows of employed workers among industries underline once again the extreme cyclical sensitivity of durable manufacturing. The industry recruited 1.16 million workers from other industries between 1964 and 1966 while dropping 0.76 million workers between 1969 and 1971. 
No other industry exhibited this scale of cyclical variability in employment.

Panel F also highlights the "interindustry feeder" role of retail tradethe supplying of experienced workers to other industries. Net exits were 1.54 million, 1.29 million, and 0.80 million for the three periods, respectively. Thus although retail trade is consistently a feeder industry, the flow depends on the state of the business cycle. Similar patterns were observed for the other three low-wage industries of this study (agriculture, household services, and other services). The net outflow from retail trade in 1966-68 was close to that for 1964-66, presumably reflecting the numerous opportunities for upgrading that low-wage workers found in the highpressure economy of that period.

Thus the representative high-wage and low-wage industries display contrasts in recruitment practices. Durable manufacturing expands employment by drawing older workers from outside of covered employment and by attracting workers from other industries (and releases them to those industries when employment shrinks). But it rarely recruits the youngest workers just entering the labor force.

In retail trade, on the other hand, 16- and 17-year-olds represent a constant flow that is not very sensitive cyclically. Adjustments occur instead in the rates at which retail trade attracts older workers from outside of covered employment and loses experienced workers to other industries. In expanding and tight labor markets, there are bigger losses to other industries which are offset by increased recruitment of older persons from outside of covered employment. Retail trade (along with agriculture, household services, and other services) can be characterized as a training ground. It hires workers with little or no previous experience and subsequently loses many of them to other industries.

\section{Job Changing and Real Wage Gains}

Associated with the employment changes just described are systematic gains in real wages. Table 2 focuses on these gains for cohorts of workers initially aged 16 to 64 and classified according to their job mobility. As before, workers in durable manufacturing and retail trade are singled out and aggregate data for all thirteen industries are given. Each panel shows gross employment flows, mean wages, and the percentage growth in mean 


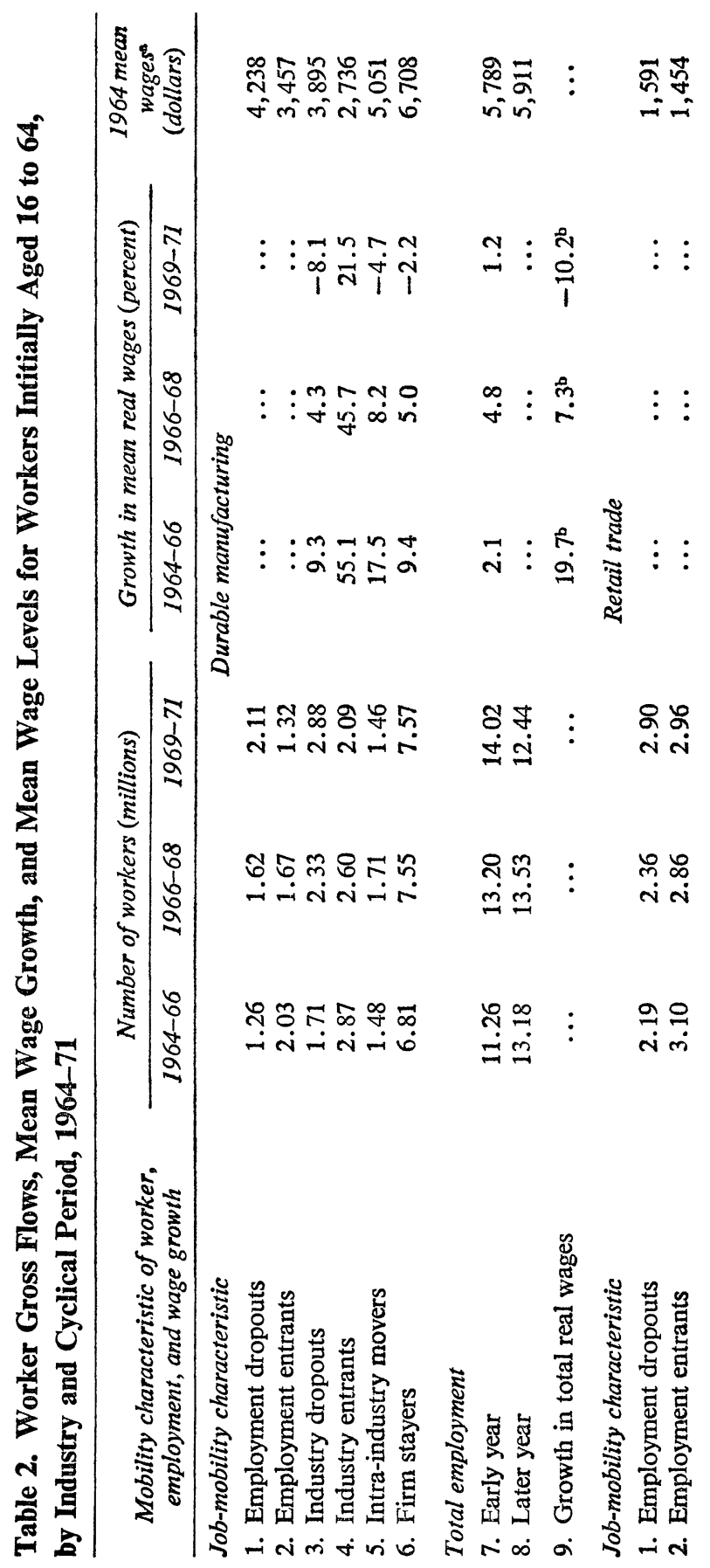




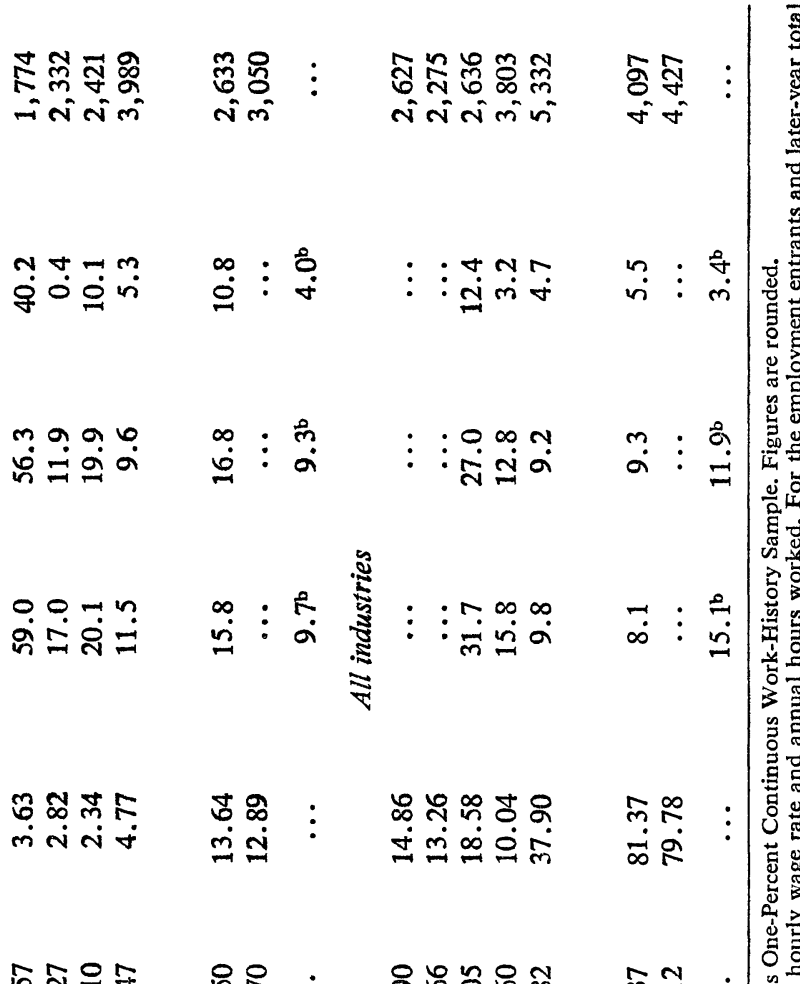

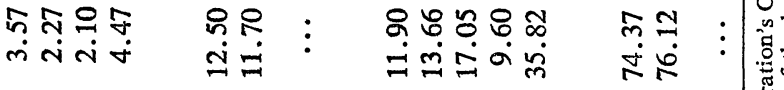

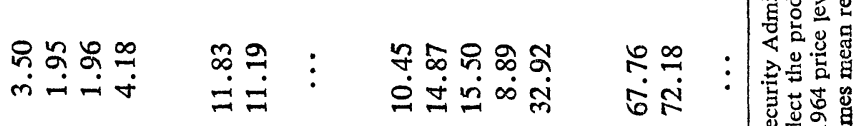
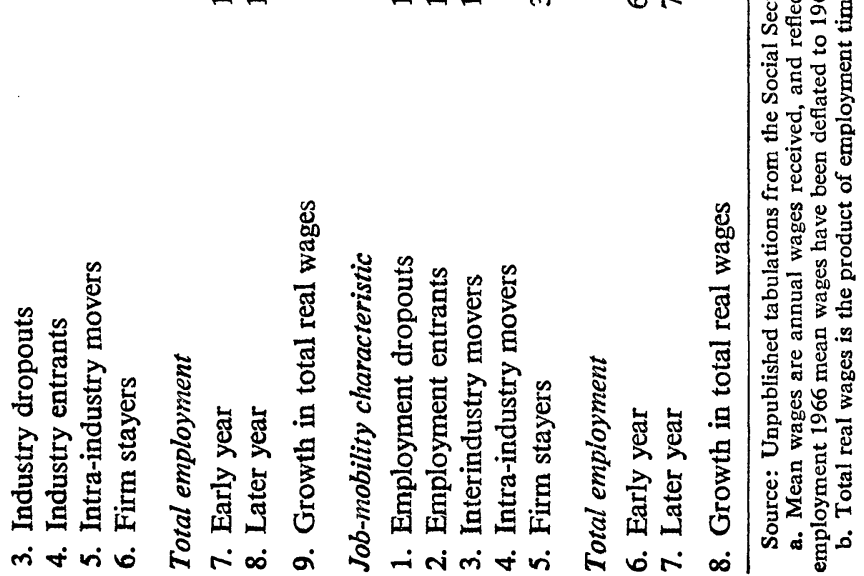
wages for workers employed in both years of a cyclical period. The jobmobility categories distinguish people who change employers but remain within the same major industry (intra-industry movers) from those who change industry. The "firm stayer" category includes all workers who remain with the same employer, even if they change their type of job (a matter that cannot be identified). The employment totals in each panel are derived from the detailed job-mobility categories; thus row 7 in the first two panels is the sum of rows $1,3,5$, and 6 , while row 8 sums rows $2,4,5$, and 6 .

Table 2 reveals extensive job changing in each cyclical period. For example, of the 11.26 million workers in durable manufacturing in 1964, only 6.81 million, or 60.5 percent, were still with the same major employer in 1966. As would be expected, employee attachment in the 1964-66 period in retail trade was much lower-4.18 million of 11.83 million, or 35.4 percent. In the aggregate, less than half of the 1964 workers had the same major employer in 1966-32.92 million of 67.76 million, or 48.6 percent.

With mean 1964 wages as a benchmark, there emerges a clear-cut hierarchy of workers according to mobility status in both durable manufacturing and retail trade. Workers who move into and out of covered employment (rows 1 and 2) and interindustry movers (rows 3 and 4) have the lowest average wages. Those who move within the industry occupy an intermediate wage level (row 5) while firm stayers earn the highest annual wages. This same hierarchy held for all industries, as is shown by the gains in the mean wage by job-mobility categories in the all-industry section of the table. The older, more experienced, and more senior workers are heavily concentrated among firm stayers, and in all industries this implies a heavy representation of white men aged 25 to 64 .

\section{DURABLE MANUFACTURING}

Within durable manufacturing, probably the most dramatic finding is the pattern of real wage gains by job-mobility category. Between 1964 and 1966 workers who left durable manufacturing for other industries experienced an average gain of 9.3 percent in real wages; but those who entered the industry received one of 55.1 percent. This discrepancy is not unexpected since durable manufacturing is characterized by high pay and 
good working conditions. The attractiveness of these jobs enabled the industry to recruit nearly 5 million workers from other industries and from outside of covered employment in the 1964-66 period. The net gain in industry employment was almost 2 million.

Between 1964 and 1966 persons who changed jobs but remained within durable manufacturing realized average real wage gains of 17.5 percent, against the 9.4 percent gain by workers who did not change jobs. The smallest proportional gains among workers employed in the industry in 1966 were realized by those in the highest wage category - that is, the firm stayers. Workers who entered durable manufacturing had the lowest 1964 average wage but the largest percentage gains. Workers who changed jobs within the industry were in the middle both in their 1964 level and in subsequent gains. Thus there is a strong inverse relation between average wage level and the real wage gain in the period.

Despite their own large wage gains, new recruits into durable manufacturing earned far less than the industry's average wage in 1966. Thus the large net recruitment shifted the composition of industry employment in favor of relatively low wages, and reduced the growth in the industry's mean wage between 1964 and 1966. For all workers the growth in mean real wages was only 2.1 percent even though each mobility group gained considerably more than that.

Many of the wage patterns of 1964-66 were repeated between 1966 and 1968. Again, the wage gains were highest for those who entered the industry and lowest for firm stayers. Because the net flow of workers into the industry was comparatively small, the mean real wage rose more than twice as rapidly as it did during 1964-66 even though the means for all of the individual mobility categories grew more slowly in the later period.

The growth of real wages in 1969-71 was far below that of the two earlier periods. Industry entrants were the only mobility group who experienced any gain, and that was substantially smaller than the comparable one in the two earlier periods. However, because employment reductions were concentrated among relatively low-wage workers, the industry's mean real wage actually increased by 1.2 percent in this period.

Involuntary mobility was undoubtedly much more prevalent in 196971 than in the two earlier periods. Following their layoffs, some workers did not secure jobs in covered employment. Others moved to lower-paying jobs in different industries, though some found jobs elsewhere in durable 
manufacturing. As a result, the highest paid and most secure workers experienced smaller percentage losses in real wages than either the industry dropouts or the intra-industry movers.

The evidence strongly supports the Okun-Thurow view of the benefits of a high-pressure economy. The biggest percentage gains in real wages in the 1964-66 and 1966-68 periods were realized by workers who entered durable manufacturing and workers who moved to other firms within the industry. On average these were low-wage workers, especially the industry entrants. Yet, given the opportunities for upgrading associated with tight labor markets, they realized much larger percentage increases in average real wages than the high-wage workers who did not change jobs. Then in 1969-71 a complete reversal occurred, and, while all workers fared less well, the change was particularly evident for the low-wage categories.

\section{RETAIL TRADE}

In one respect, the pattern of real wage gains for retail trade stands in sharp contrast to that for durable manufacturing. The largest percentage gains by far were realized consistently by workers who left the industry to work elsewhere. As noted earlier, retail trade is a feeder industry; the cohort data show a consistent outflow of about 3.5 million to other industries in each period. In 1966-68, the real wage gain for industry dropouts was 56.3 percent and even in the recessionary period 1969-71 the gain was still a substantial 40.2 percent. The business cycle influences both the number of industry entrants (and hence the net outflow) and the size of the real wage gains for dropouts and entrants. Compared with the experiences of these job changers, the real wage gains were much more stable across the three periods for workers in retail trade who did not change employers, although they were smallest in 1969-71.

\section{ALL INDUSTRIES}

One noteworthy feature of economy-wide behavior is the sheer volume of job mobility. As the bottom section of table 2 reveals, in each of the three periods at least 15 percent of the workers dropped out of covered employment. Over 20 percent of the total changed their major industrial affiliation; in this part of the table, interindustry movers refer to all workers who changed industrial affiliations. More than 10 percent moved 
within their major industry. Slightly less than hali of the workers remained with the same major employer during each period.

The evidence for the overall economy strongly reinforces earlier observations about the relation between mobility status and average wages. Persons who drop out and enter covered employment and interindustry movers have the lowest average annual wages. Those who do not change employers have the highest average wages - in fact, roughly twice as high as wages for the interindustry movers.

Percentage gains in real wages follow a pattern similar to that of durable manufacturing. Of the three groups with earnings in both years of a period-that is, rows 3, 4, and 5-interindustry movers realize by far the largest percentage gains in every interval.

The large net movements of 4.42 million workers into covered employment (as noted in panel $\mathrm{E}$ of table 1) between 1964 and 1966 introduced a substantial group with low average wages and held down the growth in the overall average. The increase in the overall mean, 8.1 percent, was below that of all three categories of two-year workers. In 1966-68, the overall mean gain rose to 9.3 percent, even though the mean for all three categories slowed. The smaller net inflow was the main reason for this contrast with 1964-66.

The aggregate effects of the 1969-71 recession on wage gains are clear. The number of dropouts exceeded the number of new entrants into covered employment by 1.60 million. Interindustry and intra-industry job changes included many more layoffs than in the earlier periods, and as a consequence the percentage wage gains associated with these moves were much smaller. The more senior workers, who are heavily concentrated in the job-stayer category, had much more stable patterns of wage increases over the three cyclical episodes.

Two strong impressions conveyed by table 2 are that cyclical adjustments in the labor market are closely related to mobility of workers among jobs, and that job changers are typically low-wage workers. The adjustment mechanisms include interindustry and intra-industry job changes as well as changes in the direction and amount of net movement into the labor force. ${ }^{10}$

Table 2 also illustrates the continuous nature of upgrading in all phases of the business cycle. Large numbers of interindustry job changers are

10. Recall that movement to zero earnings status in CWHS data includes movement to noncovered employment, to self-employment, and to unemployment. 
observed in the three periods, and those workers consistently realize the largest percentage gains in wages. Many of the moves represent changes from part-time to full-time labor force commitments by persons in their late teens and twenties, ages during which cross-section age-earnings profiles slope upward very sharply. The business cycle influences the aggregate number of new job vacancies in high-wage industries and the ratio of voluntary to involuntary job changes. Consequently, the average wage gains associated with interindustry job changes closely mirror overall conditions in the labor market. Less upgrading takes place as the economy moves into a recession.

Finally, table 2 provides a good illustration of "Holt's law."11 The rate of job changing is nearly constant during the business cycle as cyclical changes in quit rates and layoff rates largely offset one another. Retention rates by firm were 48.6 percent in $1964-66,48.2$ percent in 1966-68, and 46.6 percent in 1969-71. The slight downtrend in these rates reflects changes mainly in the demographic composition of the work force between 1964 and 1971. Among white men aged 25 to 64, the retention rates in the three periods were $58.4,59.7$, and 58.1 percent, respectively.

\section{The Demography of Cyclical Gains in Real Wages}

Because CWHS data record each worker's age, race, and sex, the underlying demographic characteristics of workers in the various jobmobility categories can also be examined. Tabulations of twenty-eight demographic groups (seven age groups and four race-sex groups) in the three cyclical periods yielded a number of predictable findings. Generally, movement into and out of covered employment and movement between industries were more frequent (as a fraction of total employment) for young, black, and female workers than for white men aged 25 to 64 . For example, white men 25 to 64 represented 43.3 percent of total employment in 1964 (29.36 million of 67.76 million) but 52.1 percent of all firm stayers in the 1964-66 period (17.15 million of 32.92 million).$^{12}$

11. Charles C. Holt, "Job Search, Phillips' Wage Relation and Union Influence: Theory and Evidence," in Edmund S. Phelps and others, Microeconomic Foundations of Employment and Inflation Theory (Norton, 1970), p. 59.

12. This is among the details on mobility differentials by demographic groups reported in my longer paper, "Cyclical Earnings Changes." 
Table 3 focuses on the payoffs to job mobility for two broad demographic groups, white men initially aged 25 to 64 and all other workers initially aged 16 to 64 . The table shows mean 1964 wages and rates of growth in real wages for both groups in the three cyclical periods. The jobmobility categories and industries are the same as before except that employment entrants and employment dropouts do not appear explicitly. ${ }^{13}$

Many of the patterns for wage levels and rates of growth in real wages by type of job mobility that apply to workers in general, reported in table 2, apply also to the two major demographic groups described in table 3. In general, interindustry movers receive the lowest annual wages while firm stayers are again the highest paid. For all three industrial categories, 1964 mean wages are far higher for white men of 25 to 64 years than for the other workers. Due to higher wage rates and longer annual hours worked, these men typically earn twice to three times as much as the other groups in durable manufacturing (the high-wage industry), in retail trade (the low-wage industry), and in the aggregate.

During 1964-66 workers who entered durable manufacturing and those who left retail trade experienced the largest percentage increases in real wages. But these percentages were much smaller for white men aged 25 to 64 than for all others: 24.0 versus 97.0 percent for those entering durable manufacturing, and 22.0 versus 88.7 percent for those leaving retail trade. The contrast in the 1964-66 employment gains for the two demographic groups-2.4 and 39.8 percent, respectively-also vividly illustrates that a high-wage industry heavily recruits persons other than white men 25 to 64 years old in a cyclical expansion.

For both demographic groups the lowest wage workers (the interindustry movers) realized the largest percentage gains in 1964-66 while the highest wage workers (the firm stayers) realized the smallest. All of the percentage gains are much higher for the residual group because it includes many young workers, who experience the most rapid earnings growth. The section on all industries illustrates the particularly large employment gain of the residual group during the 1964-66 upturn.

Real wage growth for all mobility groups was much lower during the 1969-71 downturn. Both for the two industry groups and in the aggregate, real wage growth for the firm stayers is the most cyclically stable, with the smallest difference between the 1964-66 and 1969-71 percentages. For

13. These groups were included for calculating industry mean real wages and growth in total employment. 


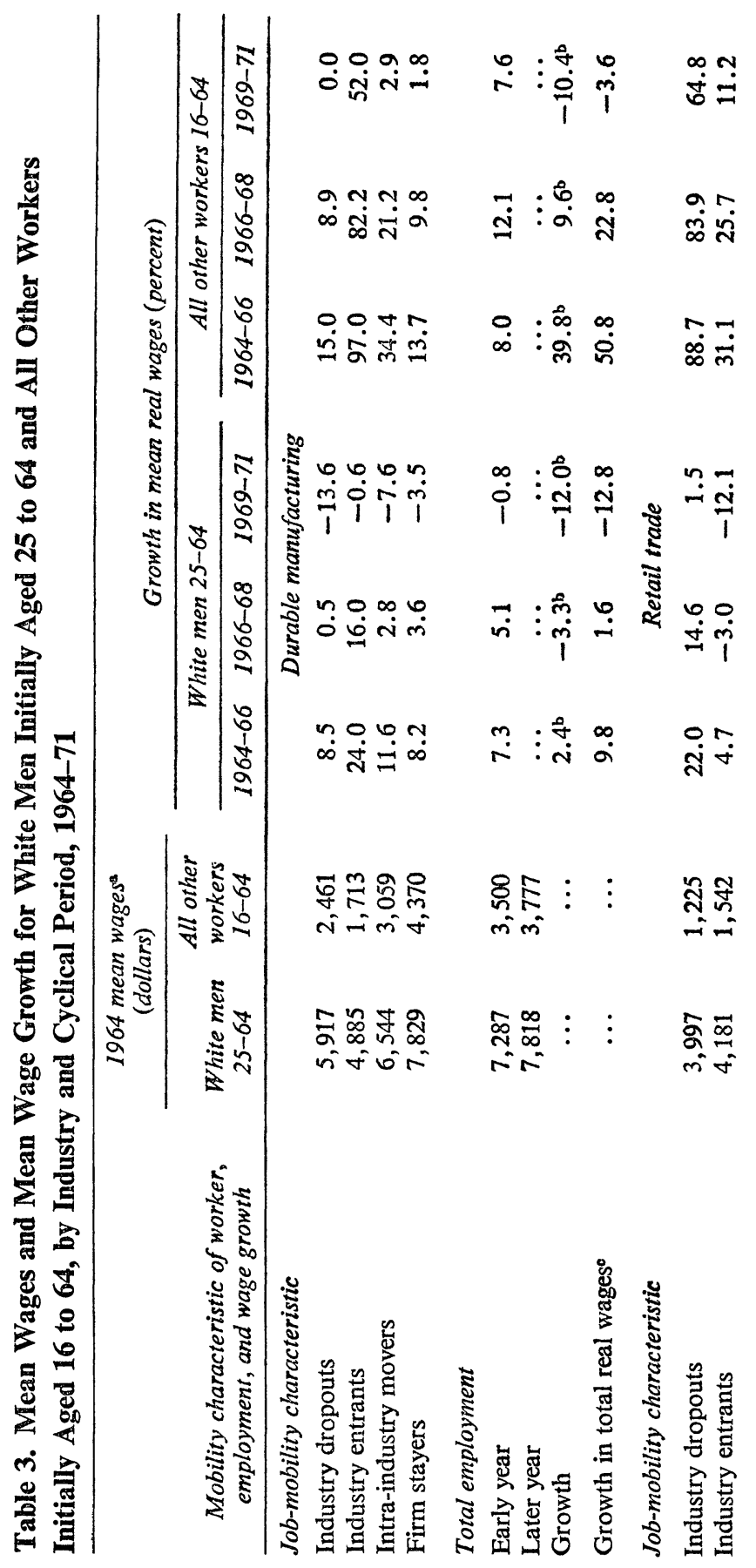




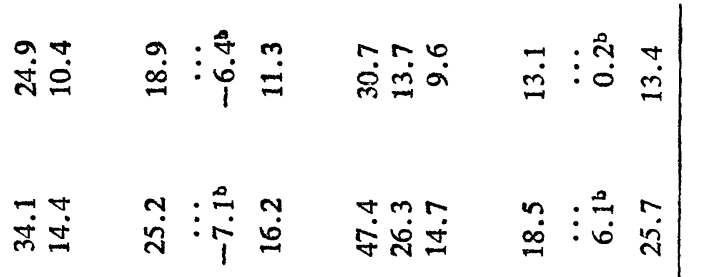

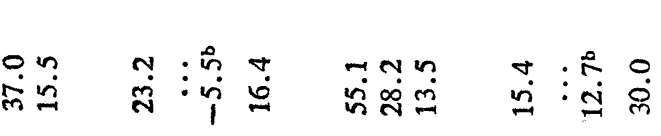

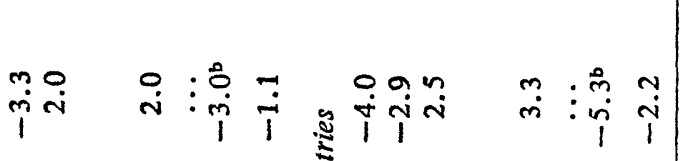

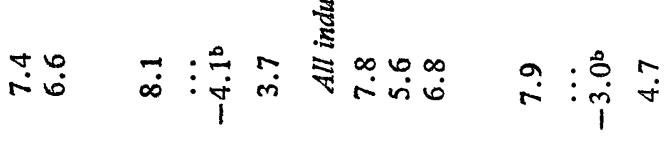

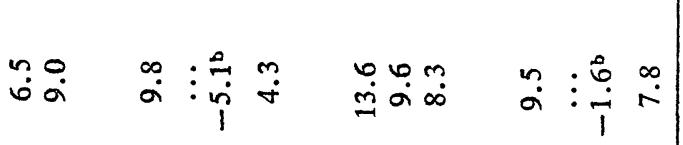

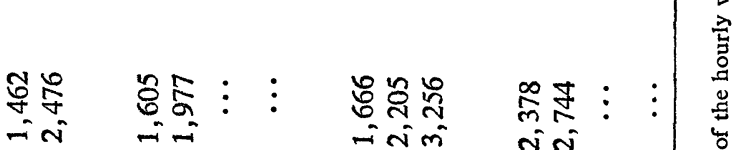

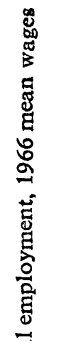

नinm तín

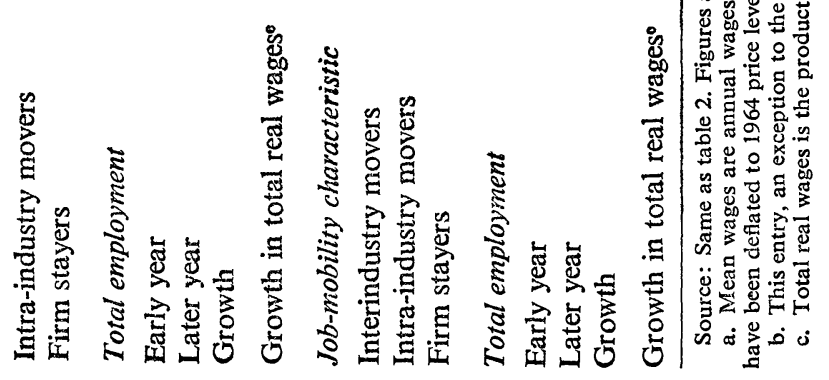


white men aged 25 to 64 , the absolute differences in the percentage changes for the two periods were $17.6(13.6$ less -4.0$)$ points for interindustry movers, 12.5 points for intra-industry movers, and 5.8 points for the firm stayers. Among all other workers the comparable differences were 24.4 (55.1 - 30.7), 14.5, and 3.9 points, respectively. Thus for both demographic groups, the interindustry movers exhibit the greatest cyclical sensitivity in real wage growth; and since the mean wage level among those other than white men of 25 to 64 years is so low ( $\$ 1,666$ in 1964), they experience the greatest variation of all.

Three observations about the 1966-68 period have general implications for a high-pressure economy. First, the workers entering durable manufacturing and leaving retail trade continued to experience especially large real wage gains in this period. These gains were closer to those of 1964-66 than to those of 1969-71. Second, the demographic composition of employment in durable manufacturing continued to shift away from white men aged 25 to 64 and toward other kinds of workers. ${ }^{14}$ Third, among these workers, growth in mean wages was about as high in 196668 as it had been in 1964-66. As a result of growth in both mean wages (18.5 percent) and employment ( 6.1 percent), these groups continued to realize very large gains in total real wages ( 25.7 percent) in the $1966-$ 68 period.

\section{Conclusions}

The findings of this paper have a number of implications for macroeconomic issues involving low-wage workers. First, there is an obvious relationship between these findings and the observed cyclical sensitivity of U.S. poverty rates. Although low annual wages and poverty status are not synonymous, they are closely related. Thus poverty rates rise in recessions because of decreases in real earnings of the "working poor." These persons are undoubtedly heavily concentrated among the employment dropouts and interindustry movers observed in this study. Second, these find-

14. The cohort data for white men aged 25 to 64 overstate employment reductions because some older workers retire in each cyclical period. When employment changes were computed with data on constant age groups for 1966 and 1968 -that is, white men 25 to 64 in 1966 and then white men 25 to 64 in 1968 - the change in employment in durable manufacturing was found to be an increase of 2.8 percent. 
ings provide some insight into the common observation of a procyclical movement in the ratio of average annual earnings of black males to those of white males. ${ }^{15}$ Although the proposition cannot be tested in CWHS data, the upgrading of black men may be important enough to cause a significant narrowing of racial differentials in wage rates during cyclical upswings. This narrowing, as well as differential unemployment experiences, may be partly responsible for the procyclical behavior of the earnings ratio.

Third, the contrasting patterns of real wage increases for job stayers and job changers observed in tables 2 and 3 are broadly consistent with a theory of the Phillips curve formulated by Robert Hall. ${ }^{16}$ In his theory, movements in the aggregate wage rate are dominated by changes in wage rates paid to newly hired workers (Hall's scale wage and marginal effective wage). Many of the interindustry and intra-industry job changers observed in this study were new hires, and these workers exhibited the most cyclical variation in the rate of real wage gain. The theory, however, would have to be validated on a data base that records hourly wage rates.

Fourth, since many types of disaggregation are possible in CWHS data, they permit assessment of the impact of changes in the demographic composition of the work force on the average amount of employee turnover. Between 1964-66 and 1969-71 the proportion of firm stayers fell from 48.6 to 46.6 percent of all workers initially aged 16 to 64 . This decline occurred even though the retention rate for white men initially aged 25 to 64 was essentially constant. The implications of these demographic changes are numerous. They may affect the full-employment or "natural" unemployment rate, or both, as well as aggregate labor productivity.

Finally, it seems appropriate to draw together some threads of evidence about the benefits of the high-pressure economy. Although the most impressive improvements for low-wage workers occur in a cyclical upswing (as reflected in the growth of total real wages reported in tables 2 and 3 ), this paper also found clear evidence of continuing benefits from the highpressure economy. Other workers aged 16 to 64 continued to make real wage gains relative to white men aged 25 to 64 in the $1966-68$ period.

15. Richard B. Freeman, "Changes in the Labor Market for Black Americans, 1948-72," BPEA, 1:1973, pp. 67-120.

16. Robert E. Hall, "The Process of Inflation in the Labor Market," $B P E A$, 2:1974, pp. 343-93. 
Also, the real wage gains of interindustry job changers were nearly as large in this period as they had been in the expansion of 1964-66 (table 2 ). Additionally, on net, more 16- and 17-year-olds were recruited into covered employment during 1966-68 than during 1964-66 (panel D of table 1). Finally, the net flow of workers out of the four low-wage industries covered here was nearly as large in these years as it had been in 1964-66. All of these events imply continuing opportunities for and realizations of large gains in real wages by low-wage workers in a maintained high-pressure economy.

\section{Discussion}

MICHAEL WACHTER was surprised by the extent of upgrading revealed in Vroman's data. He distinguished among different theories of the upgrading process and insisted that the evidence did not demonstrate the feasibility of permanent noninflationary upgrading. Noting his disagreement with Thurow, Wachter argued that the inflation that had accompanied the cyclical upgrading process in the late 1960s refuted the hypothesis that the rate of productivity growth would not slow down when lowerskilled people were placed in higher-grade activities. Arthur Okun and George Perry cautioned him not to infer that inflation had been caused by the hiring of inferior workers who did not earn their pay; inflation could result when a perfectly homogeneous labor market gets tight. The pressure on money wages, which is not related to the performance of productivity, ought to be distinguished from the price response to wage movements, which may reflect productivity.

Perry saw evidence that upgrading was permanent in table 3 , which indicates that during the 1969-71 recession interval, employment of white males in durable manufacturing declined by 12 percent whereas employment of other groups declined by 10.4 percent. Others noted, however, that it was difficult to interpret these numbers without a notion of what the noncyclical demographic effects should have been, especially in view of pronounced underlying changes in the demographic composition 
of the labor force. Vroman acknowledged that retirement would decrease, during any period, the size of the group of white males who were between 25 and 64 initially. Wachter pointed out that the normal age-cohort effect means an upgrading of males as they get older; that should also be taken into account in any inference about cyclical effects.

Edward Gramlich was interested in a comparison of what happens when low unemployment is achieved for a sustained period with what would happen if unemployment remained steadily high. The 1966-68 interval may have given an example of the first state; but there was no comparable interval of the second. Such a comparison is needed to determine the permanence of the apparent relationship between upgrading and the level of unemployment.

Several comments focused on the limitations of the data. Martin Feldstein mentioned various ways that the employment figures were distorted because the data referred only to employees covered by social security. For example, a low-wage worker who moves from domestic service to a factory job, or from agriculture to industry, would be counted as an employment gain in the figures. Okun pointed out that movements into and out of self-employment would have similar effects at the high end of the wage scale. William Poole asked what effect the taxable-wage ceiling might have had on the data for high-wage workers; Vroman informed him that estimates of earnings above the ceiling had been made; he felt that the aggregate figures probably were not defective on this account, although those for individuals were.

Robert Hall observed that the data afforded an exciting opportunity for unscrambling some of the interactions between labor turnover and wage changes. In particular, it would be interesting to separate the inflationary contributions of labor turnover from those of wage bargaining. Hall hoped that it would be possible to match the earnings data with data on industry profits and productivity, and to examine how much productivity changes during the upgrading process. He noted, however, that the earnings figures were expressed in a way that made it impossible to distinguish wage changes from changes in hours worked. To answer many relevant questions, it would be necessary to control for the increase in hours worked that accompanies the transition from the retail to the manufacturing sector.

Hall stressed that even if expansion did have these upgrading effects, 
its costs should be borne in mind. This evidence did not offer blanket justification for policies to eradicate unemployment at all costs. Okun countered that it did say something about the costs of tolerating unemployment at 7 or 8 percent levels for three years. Vroman noted that the paper disproved the contention that most of the benefits of a high-pressure economy accrue to those furthest up in the wage distribution. 